\title{
ANALYSES OF GLASS USED IN THE MANUFACTURE OF INCANDESCENT ELEC'TRIC LAMPS.
}

\author{
By Durayd Woodyan, Ph. D.
}

In the manufacture of Incandescent Lamps there is a certain percentage of loss due to what may be termed spontaneous breakage; lamps, apparently well made, cracking at some part without having been subjected to any shock or blow.

A reasonable amount of loss in this way is unavoidable, from one cause or another, but when a certain limit is exceeded some special cause is suspected, as carelessness in the glass blowing department, want of sufficient annealing, and the like.

The difficulty often passes by during the efforts to control it, without any satisfactory explanation either of the trouble or the cause of its cessation.

The lamp bulbs may crack (a) where the platinum wires are sealed in, or (b) where the "stem" carrying the wires and carbon filament is joined to the bulb proper, or occasionally (c) where the exhausting tube is sealed on at the apex of the bulb.

In addition to the internal strains existing in any such glass work, the lamp bulb, when finished, is subjected externally to the full atmospheric pressure and to sudden heat strains from the instantaneous turning on of current, as occurs in perhaps a majority of Jamps in use.

This combination of strains being considered, it is evident that differences in the glass used for the bulb and stem and consequent differences of coefficients of expansion which, in ordinary glass work would not be of importance, will become manifest here.

Glass blowers know that similar grades of glass should be ured together, but they are able to work up grades of glass differing in composition more than is permissible in incandescent lamps.

I have had an opportunity to make some analyses of the glass used at a time when the percentage of spontaneous breakage was abnormally large, and when every care in making up the lamps, annealing, etc., was unavailing. 
Analysis of Glass Rod, Tube and Lamp Bulb.

\begin{tabular}{|c|c|c|c|}
\hline & Rod, 108. & Tube, 109. & Lamp Bulb, \\
\hline $\mathrm{K}_{\mathrm{g}} \mathrm{O}$ & 1.38 & 4.20 & 2.32 \\
\hline $\mathrm{Na}_{2} \mathrm{O}$ & 15.06 & 9.0 .5 & 14.50 \\
\hline $\mathrm{CaO}$ & 8.15 & - & 6.40 \\
\hline $\mathrm{MgO}$ & 0.50 & - & 0.93 \\
\hline $\mathrm{MnO}$ & & trace. & trace. \\
\hline $\left.\begin{array}{l}\mathrm{Fe}_{2} \mathrm{O}_{3} \\
\mathrm{Al} \mathrm{O}_{3}\end{array}\right\}$ & $1.02\}$ & $1.65\}$ & 1.45 \\
\hline $\mathrm{PbO}$ & 16.81 & 19.83 & 1.39 \\
\hline $\mathrm{SiO}^{2}$ & 63.44 & 65.16 & i2.35 \\
\hline \multirow[t]{2}{*}{$\mathrm{Cr}_{2} \mathrm{O}_{3}$} & trace. & trace. & trace. \\
\hline & 100.56 & 99.89 & 99.34 \\
\hline
\end{tabular}

These results explained the trouble from breakage in lamps male up from these grades of glass.

During the investigation, samples of glass of lamps by several different makers were analyzed; one of them, an English lamp gare the following figures:

Analyses of Bulb and Stem of English Incandescent Lamp. Bulb 115. Stem 116.

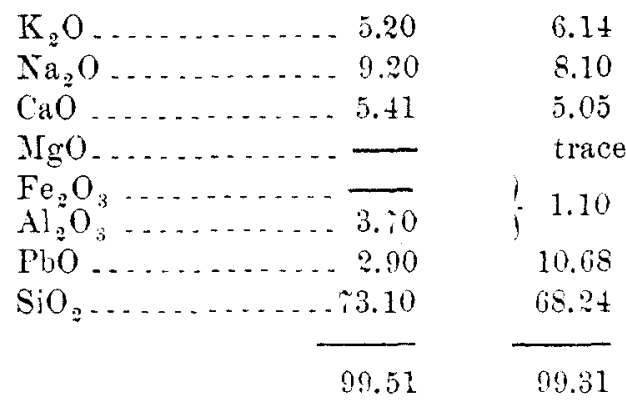

This bulb was a very brilliant clear glass. While nothing is known as to the percentage of breakage in the manufacture of these lamps, it is evident that no special effort has been made to use the same glass in both parts of the lamp. Anotier lamp (of 
American manufacture) was examined and found to be of the same glass throughout, as shown below :

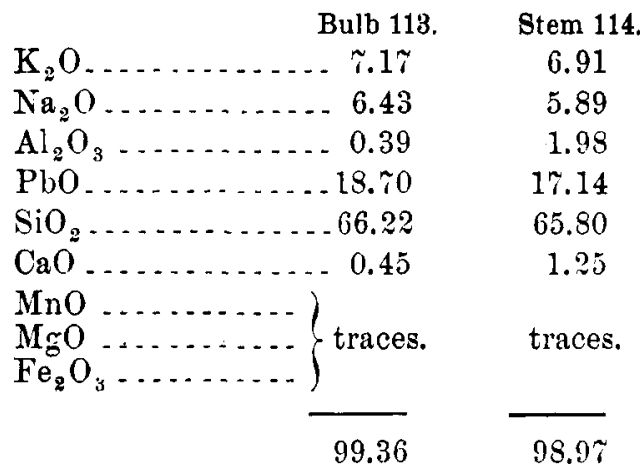

It should be said here that no proof has been obtained as to the possibility that some glasses of different composition may have similar coefficients of expansion, certain constituents compensating each other, but as it is a simple matter to obtain glass of practically the same composition for all parts of a lamp or any other complex glass work.

Problems connected with the coefficiency of expansion need not necessarily be taken into consideration.

\section{REPORT OF 'THE COMMITTEE ON SPELLING ANI) PRO-} NUNCIATION OF CHEMICAL 'TERMIS.*

During the last four years, your committee has sought to obtain from the members of this Section, from leading Ameriean Philologists, and from American Chemists in general, an exhaustive and thoroughly representative expression of opinion on the questions coming within the scope of its commissions, which has been essentially the attainment of uniformity in the orthography and pronunciation of the terms used in our science.

Three preliminary reports were distribnted to American Chem-

* From acl rance sheets of the Proceedings of the American Association for the Advancement of Science, Washington Meeting, 1891. 